\title{
Analisis Jaringan Sosial Pariwisata di Kampung Pesisir Bulak Surabaya
}

\author{
Dea Nusa Aninditya, dan Dian Rahmawati \\ Departemen Perencanaan Wilayah dan Kota, Fakultas Teknik Sipil dan Perencanaan, Institut \\ Teknologi Sepuluh Nopember (ITS) \\ e-mail:d_rahmawati@urplan.its.ac.id
}

\begin{abstract}
Abstrak-Berdasarkan RTRW Kota Surabaya tahun 2014-2034 dan RZWP3K Tahun 2012-2032, Kecamatan Bulak meliputi Kelurahan Kenjeran dan Kelurahan Bulak di kawasan kaki Suramadu diarahkan dengan fungsi utama sebagai kawasan wisata bahari/laut, pengembangan pariwisata alam dan buatan, dan permukiman nelayan. Adanya pembangunan fisik kawasan Pariwisata di Kampung Pesisir Bulak dan sekitarnya masih memyebebkan masalah non-fisik yang ditimbulkan dari adanya hubungan atau peran aktor dalam pengembangan kawasan pariwisata yang belum optimal. Untuk itu diperlukan pengembangan berbasiskan Jaringan Sosial dalam melihat hubungan dan kesinambungan antar peran dalam menyelesaikan masalah terkait pengembangan wisata di Kampung pesisir Bulak dan sekitarnya. Penelitian ini menggunakan Social Network Analysis (SNA) dalam menganalisis hubungan yang terjadi antar pihak yang berpengaruh dari kelompok pemerintah maupun kelompok organisasi masyarakat. Dalam melakukan Social Network Analysis (SNA) mengacu pada perhitungan Degree of Centrality, Closeness Centrality dan Betweenness Centrality dari setiap aktor yang teridentifikasi. Kemudian dari hasil analisis menunjukkan bahwa Dinas Pertanian bidang Perikanan dan Badan Perencana Pembangunan Kota Surabaya merupakan pihak yang memiliki nilai centrality tertinggi sehingga memiliki peran yang besar dalam pengembangan pariwisata kampug pesisir Bulak Surabaya.
\end{abstract}

Kata Kunci-Kampung, Pesisir, Pariwisata, Bulak, Jaringan Sosial.

\section{PENDAHULUAN}

$\mathrm{K}^{\mathrm{s}}$ AWASAN pesisir merupakan daerah yang sensitif dan rapuh baik dari segi fisik geografis, karakteristik alam, keanekaragaman hayati dan juga secara sosial dimana terdapat berbagai kepentingan dan pengelolaan oleh berbagai pihak di kawasan pesisir yang sangat terkait dan dipengaruhi kondisi di darat dan di laut, sehingga rentan terhadap adanya aktivitas manusia [1]. Kota Surabaya merupakan salah satu Kota dengan ciri pesisir yang kuat, dimana arah pertumbuhan Kota berawal dari kawasan pesisirnya. Ditunjang dengan garis pantai sejauh $47,4 \mathrm{~km}$, dan potensi perikanan di kawasan pantai Timur hingga 3.922,5 ton per-tahun dengan jumlah nelayan sebanyak 2.226 orang menunjukkan adanya penggunaan dan pemanfaatan kawasan pesisir dengan fungsi perikanan dan juga pariwisata serta permukiman, utamanya permukiman nelayan [2]. Pengembangan permukiman pesisir memiliki peran vital dalam kegiatan ekonomi dikarenakan terdapatnya integrasi antara fungsi ekonomi dan fungsi budaya [3].

Potensi pariwisata pesisir di Kecamatan Bulak dapat dicerminkan melalui adanya peningkatan kunjungan wisatawan mancanegara ke kawasan Kenjeran dan Bulak sebanyak 200an wisatawan mancanegara di tahun 2013, dan meningkat menjadi 300-an wisman pada tahun 2014 [4]. Peningkatan potensi pariwisata di Kawasan Pesisir Bulak juga dilakukan oleh Pemerintah Kota Surabaya dengan perencanaan landmark baru di Kawasan Surabaya dengan optimalisasi Sentra Ikan Bulak (SIB), Jembatan Kenjeran dan Taman Bulak. Potensi pariwisata potensial dikembangkan yakni kampung nelayan yang merupakan salah satu kearifan lokal kawasan yang bersinergi dengan pengembangan kawasan wisata Bulak dan Kenjeran serta keindahan pemandangan matahari terbit [5].

Namun, hingga saat ini persiapan dan pengelolaan kawasan wisata pesisir Bulak belum optimal, hal ini ditandai dengan minimnya jumlah pengunjung ke Sentra Ikan Bulak dan Kawasan Pariwisata di sekitarnya dan juga masih banyaknya program maupun kebijakan pemerintah yang belum terimplementasi optimal di Kawasan Pesisir Bulak [6]. Hingga saat ini, pengembangan kawasan kampung wisata pesisir Bulak melibatkan berbagai elemen lembaga (multisektor) didalamnya baik pemerintah dalam menetapkan kebijakan dan program, serta masyarakat sebagai obyek dan subyek pengembangan. Namun, adanya program program pengembangan kawasan wisata kampung pesisir Bulak seringkali belum optimal pelaksanaannya di tingkat implementasi kepada masyarakat dan kawasan kampung wisata dikarenakan kurang sinkronnya pelaksanaan peran masing masing sektor dalam pengembangan kawasan wisata kampung Pesisir Bulak.

Permasalahan tersebut mengindikasikan belum efektifnya peran antar kelembagaan yang berwenang dalam pengembangan kawasan kampung wisata pesisir Bulak sehingga dibutuhkan suatu penelitian terkait penguatan peran tiap kelembagaan melalui jaringan sosial yang menaungi pengembangan kawasan.

\section{METODE PENELITIAN}

\section{A. Pendekatan Penelitian dan Variabel Penelitian}

Pendekatan yang digunakan dalam penelitian ini yakni pendekatan rasionalistik. Pendekatan rasionalistik bersifat membangun kebenaran teori secara empiri atau bersumber dari fakta empiri. Sedangkan variabel penelitian merupakan hal 
yang menjadi obyek amatan dalam proses penelitian ini. Berdasarkan hasil tinjauan pustaka, didapatkan variabel penelitian yang menjadi dasar proses analisis.

Tabel 1.

Variabel dan Definisi Operasional

\begin{tabular}{|c|c|c|}
\hline No & Variabel Penelitian & Definisi Operasional \\
\hline 1 & $\begin{array}{l}\text { Kelembagaan Terkait } \\
\text { Pengembangan Wisata } \\
\text { Pesisir }\end{array}$ & $\begin{array}{l}\text { Lembaga dan Organisasi yang terkait } \\
\text { dengan pengembangan wisata Pesisir di } \\
\text { Kawasan Bulak }\end{array}$ \\
\hline 2 & $\begin{array}{l}\text { Kegiatan dan Program } \\
\text { Lembaga dalam } \\
\text { Pengembangan Wisata } \\
\text { Pesisir }\end{array}$ & $\begin{array}{l}\text { Kegiatan dan Program yang pernah } \\
\text { dilakukan lembaga lembaga dan organisasi } \\
\text { dalam pengembangan kawasan wisata } \\
\text { Pesisir Bulak }\end{array}$ \\
\hline 3 & $\begin{array}{l}\text { Bentuk Kolaborasi } \\
\text { Pengembangan } \\
\text { Kawasan Pariwisata } \\
\text { Pesisir }\end{array}$ & 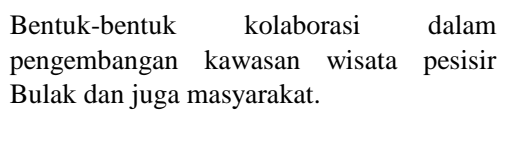 \\
\hline
\end{tabular}

Sumber: Hasil Sintesa Pustaka, 2016

Kawasan penelitian berada di Kecamatan Bulak dan terletak pada 2 Kelurahan yakni Kelurahan Kenjeran dan Kelurahan Kedung Cowek. Berikut merupakan peta kawasan penelitian.

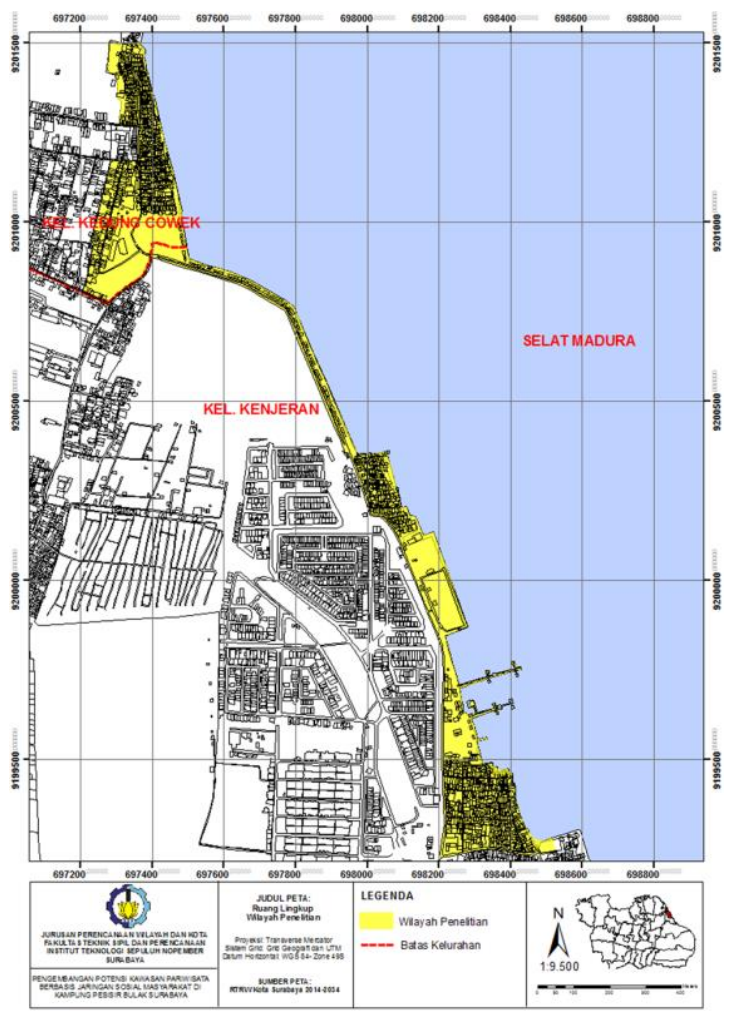

Gambar 1. Delineasi Wilayah Penelitian.

Sumber: Hasil Analisis, 2017

\section{B. Teknik Pengumpulan Data}

Sampel adalah sebagian atau wakil populasi yang diteliti. Jika kita hanya akan meneliti sebagian dari populasi, maka penelitian tersebut disebut penelitian sampel [7]. Sampel dalam penelitian ini menggunakan teknik non probabilistik dengan penarikan sampel melalui stakeholder analysis sehingga didapatkan sampel penelitian sebanyak 12 stakeholder yakni:

Tabel 2.

Sampel Penelitian Berdasarkan Hasil Stakeholder Analysis

\begin{tabular}{cc}
\hline \hline No & Stakeholder \\
\hline 1 & Badan Perencanaan Pembangunan Kota Surabaya \\
\hline \hline
\end{tabular}

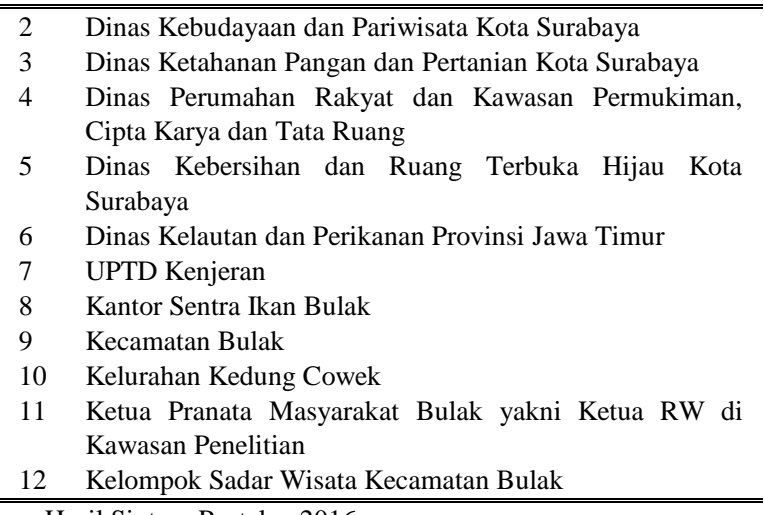
Sumber: Hasil Sintesa Pustaka, 2016

Pengumpulan data dilakukan menggunakan 2 metode yakni survey primer berupa observasi dan kuisioner serta survey sekunder dilakukan melalui studi penelitian terkait tinjauan tori yang berkaitan dengan pembahasan studi maupun dari literatur lain yang menunjang pengumpulan data seperti dokumen rencana, serta dokumen penelitian terdahulu yang memiliki keterkaitan dengan wilayah penelitian.

\section{Metode Analisis}

Analisis yang dilakukan terbagi menjadi 6 tahapan sebagai berikut.

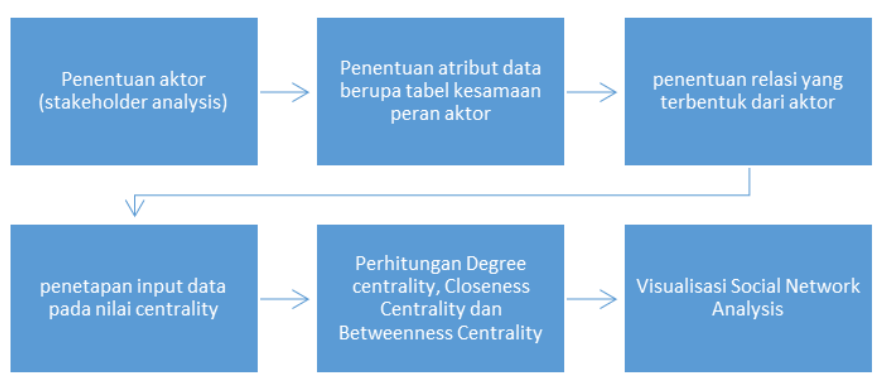

Gambar 2. Bagan Alur Metode Analisis.

Sumber: Hasil Analisis, 2017

Pendekatan SNA digunakan untuk penelitian sosial seperti memetakan arus informasi vertikal dan lateral, mengidentifikasi sumber-sumber dan tujuan untuk mencari batasan atas resourses. Social Network Analysis (SNA) adalah suatu alat yang digunakan untuk memetakan hubungan pengetahuan penting dalam jaringan sosial antara individu analisis ini dapat digunakan untuk keperluan pengambilan informasi, termasuk hubungan interaksi dan pertemanan antar user, dimana interaksi antar user dan hubungan pertemanan dapat direpresentasikan dalam grafik [8]. Selain itu, pandangan lain menyebutkan bahwa Social Network Analysis adalah proses pemetaan dan pengukuran relasi antara orang ke orang [9].

Perhitungan nilai centrality dilakukan pada 3 jenis centrality berbeda yakni Degree Centrality, Closeness Centrality dan Betweenness Centrality yang pada akhirnya dari nilai perhitungan tersebut ditampilkan melalui visualisasi Social Network yang terbentuk dari relasi yang terjadi antar aktor yang teridentifikasi pada tahap sampling menggunakan Stakeholder Analysis.

Perhitungan Degree of Centrality yakni derajat keberadaan dan posisi aktor dalam jaringan sosial yang menggambarkan 
simpul keterkaitan aktor/node. Degree Centrality mengukur peran dari sebuah aktor dalam sebuah jaringan. Bila derajat centrality tinggi maka aktor tersebut memiliki banyak hubungan dengan aktor lain. Aktor dengan degree centrality tertinggi menunjukkan bahwa aktor tersebut cukup "populer atau terkenal" dalam sebuah jaringan menggunakan persamaan (1) sebagai berikut.

$$
\begin{array}{ll}
C_{D}(i)=\frac{d(i)}{n-1} & \\
C_{D}(i) & : \text { Degree Centrality dari sebuah aktor } \\
d(i) & : \text { Derajat (jumlah edge) dari node aktor } \\
n-1 \quad & \text { Nilai maksimum degree (n merupakan } \\
& \text { jumlah total aktor dalam sebuah jaringan) }
\end{array}
$$

Closeness Centrality adalah ukuran seberapa jauh informasi dapat tersebar dari satu aktor ke aktor lainnya dalam sebuah jaringan sosial melalui pengukuran jalur terpendek antara node/aktor yang dijangkau. Semakin tinggi nilai kedekatan satu aktor dengan aktor lainnya maka semakin dekat posisi dan hubungan sehingga semakin mudah antar aktor tersebut menyebarkan informasi dalam sebuah jaringan.

Untuk mendapatkan nilai Closeness Centrality dilakukan melalui perhitungan matematis dengan persamaan (2).

$$
\begin{aligned}
& C_{C}(i)=\frac{n-1}{\sum_{j=1}^{n} d(i, j)} . \\
& C_{c}(i) \quad: \text { Closeness Centrality dari sebuah aktor } \\
& n-1 \quad: \text { Jumlah Seluruh Aktor dikurangi } 1 \\
& \sum_{j=1}^{n} d(i, j) \quad: \text { Jumlah jarak terpendek dari aktor i ke } \mathrm{j}
\end{aligned}
$$

Betweeness Centrality merupakan seberapa jauh aktor dapat mengendalikan alur informasi diantara aktor aktor dalam jaringan tersebut. Semakin tinggi betweeness centrality suatu aktor, maka aktor tersebut memiliki kapasitas dalam memfasilitasi interaksi antar aktor yang terhubung.

Perhitungan Betweenness Centrality didasarkan atas perhitungan matematis dengan persamaan (3).

$$
\begin{array}{ll}
C_{B}^{\prime}(i)= & \frac{2 \sum_{j<k} \frac{p_{j k}(i)}{p_{j k}}}{(n-1)(n-2)} . \\
C_{B}(i) \quad: \text { Nilai betwenness centrality } \\
P_{j k}(i) \quad \quad \text { Jumlah jalur terpendek yang melewai } i \\
P_{j k} \quad \text { Jumlah jalur terpendek } \\
n & \quad \text { Jumlah seluruh aktor (node) }
\end{array}
$$

\begin{tabular}{|c|c|c|}
\hline $\begin{array}{c}\text { ID } \\
\text { Aktor }\end{array}$ & Nama Aktor & $\begin{array}{c}\text { Jumlah } \\
\text { Edge }\end{array}$ \\
\hline V1 & Badan Perencana Pembangunan Kota Surabaya & 8 \\
\hline V2 & Dinas Kelautan dan Perikanan Provinsi Jawa Timur & 2 \\
\hline V3 & Dinas Kebudayaan dan Pariwisata Kota Surabaya & 19 \\
\hline V4 & $\begin{array}{l}\text { Dinas Perumahan Rakyat dan Kawasan } \\
\text { Permukiman Pekerjaan Umum dan Tata Ruang } \\
\text { Kota Surabaya }\end{array}$ & 7 \\
\hline V5 & $\begin{array}{l}\text { Dinas Ketahanan Pangan dan Pertanian Kota } \\
\text { Surabaya }\end{array}$ & 11 \\
\hline V6 & $\begin{array}{l}\text { Dinas Kebersihan dan Ruang Terbuka Hijau Kota } \\
\text { Surabaya }\end{array}$ & 9 \\
\hline V7 & Kantor Sentra Ikan Bulak Kota Surabaya & 7 \\
\hline V8 & Kantor UPTD Kenjeran Kota Surabaya & 7 \\
\hline V9 & Kecamatan Bulak Kota Surabaya & 10 \\
\hline V10 & Kelurahan Kedung Cowek Kota Surabaya & 8 \\
\hline V11 & Ketua RW Kedung Cowek Kota Surabaya & 7 \\
\hline V12 & Kelompok Sadar Wisata Kecamatan Bulak & 7 \\
\hline
\end{tabular}

Visualisasi dari hasil perhitungan diabarkan dari setiap degree yang teridentifikasi dan juga visualisasi keseluruhan dengan bantuan perangkat lunak pengolah data Social Network.

\section{HASIL DAN PEMBAHASAN}

\begin{tabular}{|c|c|c|}
\hline Nama Aktor & ID Aktor & $\begin{array}{c}\text { Degree } \\
\text { Centrality }\end{array}$ \\
\hline $\begin{array}{l}\text { Dinas Ketahanan Pangan dan Pertanian Kota } \\
\text { Surabaya }\end{array}$ & V5 & 1 \\
\hline Kecamatan Bulak Kota Surabaya & V9 & 0,91 \\
\hline $\begin{array}{l}\text { Dinas Kebudayaan dan Pariwisata Kota } \\
\text { Surabaya }\end{array}$ & V3 & 0,91 \\
\hline $\begin{array}{l}\text { Dinas Kebersihan dan Ruang Terbuka Hijau } \\
\text { Kota Surabaya }\end{array}$ & V6 & 0,82 \\
\hline Badan Perencana Pembangunan Kota Surabaya & V1 & 0,72 \\
\hline Ketua RW Kedung Cowek Kota Surabaya & V11 & 0,64 \\
\hline Kelurahan Kedung Cowek Kota Surabaya & V10 & 0,64 \\
\hline Kelompok Sadar Wisata Kecamatan Bulak & V12 & 0,64 \\
\hline Kantor UPTD Kenjeran Kota Surabaya & V8 & 0,64 \\
\hline Kantor Sentra Ikan Bulak Kota Surabaya & V7 & 0,64 \\
\hline $\begin{array}{l}\text { Dinas Perumahan Rakyat dan Kawasan } \\
\text { Permukiman Pekerjaan Umum dan Tata Ruang } \\
\text { Kota Surabaya }\end{array}$ & V4 & 0,64 \\
\hline $\begin{array}{l}\text { Dinas Kelautan dan Perikanan Provinsi Jawa } \\
\text { Timur }\end{array}$ & V2 & 0,19 \\
\hline
\end{tabular}

Dalam memudahkan perhitungan, nama aktor diberikan ID sehingga mempersingkat dan memudahkan penulisan serta diidentifikasi edge (hubungan) yang terbentuk dengan aktor lainnya.
Tabel 3

.Penamaan ID dari Setiap Aktor Teridentifikasi

Sumber: Hasil Analisis, 2017

\section{A. Hasil Perhitungan Degree Centrality}

Berikut merupakan tabel hasil perhitungan Degree Centrality dan diurutkan dari nilai terbesar ke nilai terkecil.

Tabel 4.

Hasil Perhitungan Degree Centrality

Sumber: Hasil Analisis, 2017

\section{B. Hasil Perhitungan Closeness Centrality}

Berikut merupakan tabel hasil perhitungan Closeness Centrality dan diurutkan dari nilai terbesar ke nilai terkecil.

Tabel 5.

Hasil Perhitungan Closeness Centrality

\begin{tabular}{lcc}
\hline \hline \multicolumn{1}{c}{ Nama Aktor } & $\begin{array}{c}\text { ID } \\
\text { Aktor }\end{array}$ & $\begin{array}{c}\text { Closeness } \\
\text { Centrality }\end{array}$ \\
\hline $\begin{array}{l}\text { Dinas Ketahanan Pangan dan Pertanian Kota } \\
\text { Surabaya }\end{array}$ & V5 & 1 \\
\hline \hline
\end{tabular}




\begin{tabular}{|c|c|c|}
\hline $\begin{array}{l}\text { Dinas Kebudayaan dan Pariwisata Kota } \\
\text { Surabaya }\end{array}$ & V3 & 0,91 \\
\hline Kecamatan Bulak Kota Surabaya & V9 & 0,91 \\
\hline $\begin{array}{l}\text { Dinas Kebersihan dan Ruang Terbuka Hijau } \\
\text { Kota Surabaya }\end{array}$ & V6 & 0,85 \\
\hline Badan Perencana Pembangunan Kota Surabaya & V1 & 0,79 \\
\hline $\begin{array}{l}\text { Dinas Perumahan Rakyat dan Kawasan } \\
\text { Permukiman Pekerjaan Umum dan Tata Ruang } \\
\text { Kota Surabaya }\end{array}$ & V4 & 0,73 \\
\hline Kantor Sentra Ikan Bulak Kota Surabaya & V7 & 0,73 \\
\hline Kantor UPTD Kenjeran Kota Surabaya & V8 & 0,73 \\
\hline Kelurahan Kedung Cowek Kota Surabaya & V10 & 0,73 \\
\hline Ketua RW Kedung Cowek Kota Surabaya & V11 & 0,73 \\
\hline Kelompok Sadar Wisata Kecamatan Bulak & V12 & 0,73 \\
\hline $\begin{array}{l}\text { Dinas Kelautan dan Perikanan Provinsi Jawa } \\
\text { Timur }\end{array}$ & $\mathrm{V} 2$ & 0,55 \\
\hline
\end{tabular}

Sumber: Hasil Analisis, 2017

\section{Hasil Perhitungan Betweeness Centrality}

Berikut merupakan tabel hasil perhitungan Closeness Centrality dan diurutkan dari nilai terbesar ke nilai terkecil.

Tabel 6.

Hasil Perhitungan Closenes Centrality

\begin{tabular}{|c|c|c|}
\hline Nama Aktor & ID Aktor & $\begin{array}{c}\text { Betweenness } \\
\text { Centrality }\end{array}$ \\
\hline $\begin{array}{l}\text { Dinas Ketahanan Pangan dan Pertanian Kota } \\
\text { Surabaya }\end{array}$ & V5 & 5,14 \\
\hline $\begin{array}{l}\text { Badan Perencana Pembangunan Kota } \\
\text { Surabaya }\end{array}$ & V1 & 3,4 \\
\hline $\begin{array}{l}\text { Dinas Kebudayaan dan Pariwisata Kota } \\
\text { Surabaya }\end{array}$ & V3 & 2,19 \\
\hline Kecamatan Bulak Kota Surabaya & V9 & 1,94 \\
\hline $\begin{array}{l}\text { Dinas Kebersihan dan Ruang Terbuka Hijau } \\
\text { Kota Surabaya }\end{array}$ & V6 & 1,6 \\
\hline Kelompok Sadar Wisata Kecamatan Bulak & V12 & 0,8 \\
\hline $\begin{array}{l}\text { Dinas Perumahan Rakyat dan Kawasan } \\
\text { Permukiman Pekerjaan Umum dan Tata } \\
\text { Ruang Kota Surabaya }\end{array}$ & V4 & 0,4 \\
\hline Kantor UPTD Kenjeran Kota Surabaya & V8 & 0,39 \\
\hline Kantor Sentra Ikan Bulak Kota Surabaya & V7 & 0,34 \\
\hline Kelurahan Kedung Cowek Kota Surabaya & V10 & 0,34 \\
\hline Ketua RW Kedung Cowek Kota Surabaya & V11 & 0,34 \\
\hline $\begin{array}{l}\text { Dinas Kelautan dan Perikanan Provinsi Jawa } \\
\text { Timur }\end{array}$ & $\mathrm{V} 2$ & 0 \\
\hline
\end{tabular}

Sumber: Hasil Analisis, 2017

\section{Visualisasi Jaringan Sosial Pariwisata Kampung Pesisir Bulak}

Setelah perhitungan degree tiap aktor didapatkan maka dilakukan visualisasi dengan memperhatikan jumlah jumlah hubungan dengan aktor lain (edge) serta kekuatan hubungan satu aktor dengan aktor lain dalam jaringan (weight) menggunakan perangkat lunak visualisasi Social Network.

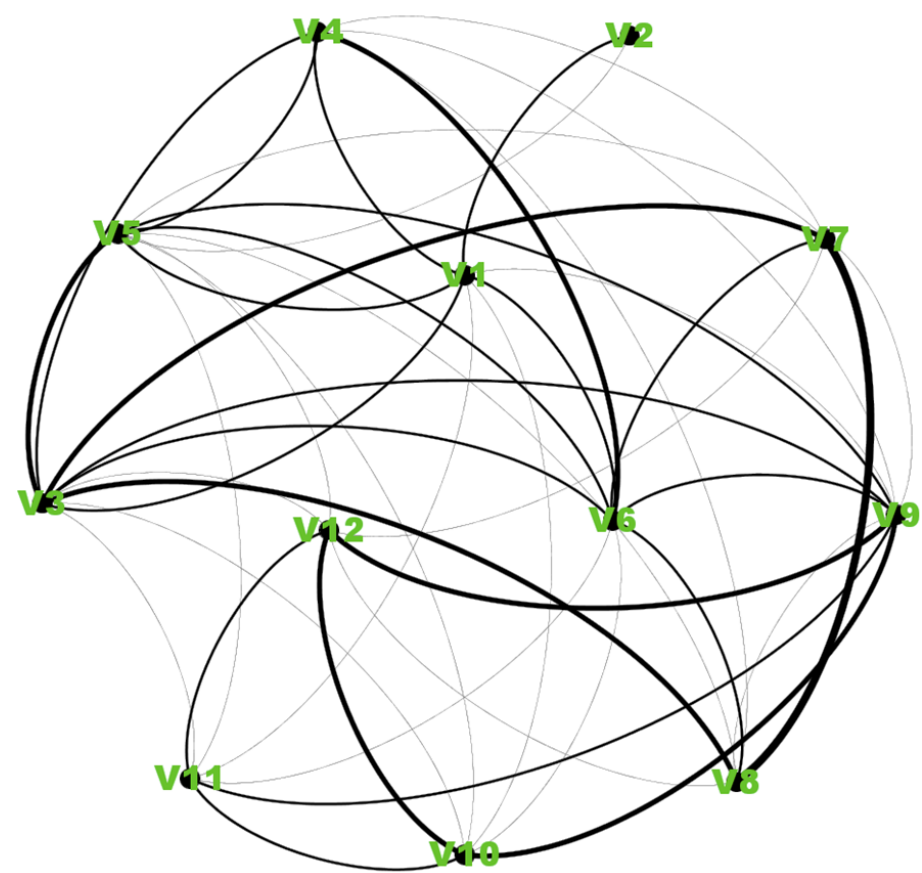

Gambar 3. Hasil Visualisasi Jaringan Sosial.

\section{KESIMPULAN}

Berdasarkan hasil analisis yang telah dilakukan dapat disimpulkan bahwa :

1. Degree Centrality dan Weight dari Nodes berdasarkan perhitungan ini didapatkan bahwa Dinas Ketahanan Pangan dan Pertanian bidang perikanan Surabaya menjadi aktor sentral dimana aktor ini memiliki peran yang sentral dalam pengembangan pariwisata kampung pesisir Bulak dikarenakan adanya pengembangan pariwisata di kawasan ini bercirikan pesisir dan perikanan yang kuat. Selain itu ada pula aktor sentral lain yakni Dinas Kebudayaan dan Pariwisata selaku pengembang pariwisata, Kecamatan Bulak selaku penghubung kelompok Pemerintah dan Kelompok masyarakat.

2. Dilihat dari Closeness Centrality, yang mengindikasikan kemudahan komunikasi berupa hubungan langsung antar aktor tertinggi dimiliki oleh Dinas Ketahanan Pangan dan Pertanian bidang perikanan Surabaya dimana memiliki banyak kesamaan peran dengan aktor lain dalam jaringan sosial atas upaya pengembangan pariwisata kampung pesisir Bulak.

3. Betweenness Centrality mengindikasikan pentingnya sebuah aktor dalam jaringan sebagai penghubung antar aktor. Nilai tertinggi yakni Dinas Ketahanan Pangan dan Pertanian bidang perikanan Surabaya yang juga memiliki Degree Centrality tinggi dan mampu menghubungkan antar aktor. Selanjutnya yakni Badan Perencana Pembangunan Kota Surabaya mampu mengendalikan jalur informasi serta menyebarkan rencana pengembangan pariwisata kawasan kampung pesisir Bulak kepada aktor teknis lain secara efektif. 


\section{DAFTAR PUSTAKA}

[1] M. D. Hasanzadeh, The application of Analytical Network Process to environmental prioritizing criteria for coastal oil jetties site selection in Persian Gulf coasts (Iran). Ocean Coastal Management, 2013.

[2] R. Rahmawati, D., \& Suprihardjo, "Identifikasi Pola Perkembangan Permukiman Pesisir Melalui Pendekatan Ekistic Studi Kasus: Wilayah Pesisir Brondong-Paciran Lamongan,” J. Penataan Ruang, 2017.

[3] Pemerintah Provinsi Jawa Timur, Profil Perikanan Jawa Timur. Surabaya, 2015.

[4] UPTD Kenjeran, Laporan Kunjungan Wisata 2015. 2015.

[5] Pemerintah Kota Surabaya, "Home: Berita. Retrieved from Website Resmi Pemerintah Kota Surabaya," 2015. [Online]. Available: http://www.surabaya.go.id.

[6] Kabar Surabaya, "Berita: Event dan Wisata. Retrieved from Website Kabar Surabaya," 2016. [Online]. Available: http://kabarsurabaya.org.

[7] S. Arikunto, Prosedur Penelitian: Suatu Pendekatan Praktik. Jakarta: Rineka Cipta, 2006.

[8] S. D. Pyrke, Analysing construction project coalitions: exploring the application of social network analysis. Construction Management and Economics, 2004.

[9] L. C. Freeman, Centrality in Social Networks II. 1979. 